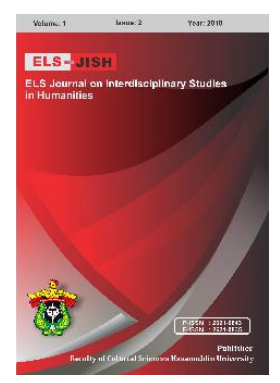

ELS-JISH

ELS Journal on Interdisciplinary Studies on Humanities

Volume 1 Issue 2, 2018

ISSN (print) : 2621-0843

ISSN (online) : 2621-0835

Homepage : http://journal.unhas.ac.id/index.php/jish

\title{
A Comparative Study on Personal Deixis of English and Tukang Besi Language
}

\author{
Farah Novianty ${ }^{1}$, Noer Jihad Saleh ${ }^{2}$, Sukmawaty ${ }^{3}$ \\ e-mail of Corresponding Author: takafulfarah@gmail.com
}

\begin{abstract}
The research is about deixis expression in English and Tukang Besi language. This reasearch attempts to describe types of deixis in English and Tukang Besi language. Descriptive qualitative method is used to reveal the types of deixis that used in English and Tukang besi with contrastive analysis to find out the differences and similarities between personal deixis of English and Tukang Besi language. the total number of subject personal pronouns in English is seven: I, He, She, It, You, We, and They; while in Tukang Besi, there are also seven personal pronouns, they are; yaku,kita, kami, ko'o, komiu, iya, ammai. There are no word which has same meaning with "it" in Tukang Besi. Tukang Besi People only use the name of things directly without use an "it".
\end{abstract}

Keywords: : Personal Pronoun, Context, Speaker, Deictic

How to cite: Farah, N. (2018). A Comparative Study on Personal Deixis of English and Tukang Besi Language. ELS Journal on Interdisciplinary Studies in Humanities, 1 (2), 226-231.

\section{Introduction}

Language is a means of forming and storing ideas as reflections of reality. In Oxford learner's pocket dictionary, language means 'a system of communication in speech and writing used by people of a particular country'. From the definition above, It is clear that language is a system. And as a system, language can be observed and learned. In this point, Communication will proceed in a good way if the target language is used appropriately. It means that the language used in accordance with the circumstances of the speaker. The use of such language called pragmatic. According to Levinson, pragmatic is the study about the grammatical relation between language (text) and context (Levinson,1983).

One of the prestigious study about Pragmatic is the study of Deixis. Levinson (1983) states that, deixis is an important part of the study of the pragmatics that concerns itself to the ways in which languages encode ... features of the context of utterance ... and thus also concerns ways in which the interpretation of utterance/es depends on the analysis of that context of utterance. Deixis is one of the most salient universals of natural language. So the study about deixis also appear in cross cultural study, especially the ways in which different languages link utterances to pragmatic factors such as speech time, speech place, and speech participants show a rich variation.

${ }^{1}$ Faculty of Cultural Sciences, Hasanuddin University 
In English, familiar ways in which deictic-roles are encoded in language are personal, spatial and temporal deixis. Deictic expressions are traditionally divided into three categories: person, place and time. For Levinson (1983:64), deixis is organized in an egocentric way, constituting the deictic center as follows: (i) the central person is the speaker, (ii) the central time is the time at which the speaker produces the utterance, (iii) the central place is the speaker's location at utterance time or coding time, (iv) the discourse center is the point which the speaker is currently at in the production of his utterance, and (v) the social center is the speaker's social status and rank, to which the status or rank of addressees or referents is relative.

Commonly, there are three deictic expression in English, they are personal deictic, spatial deictic and temporal deictic. Personal deictic such as the usage of I, we, you, she, he, them, they, etc. Temporal deictic such as the usage of now, then, tomorrow, yesterday, today, etc. and spatial deictic such as demonstratives (ie. that, what, this) and locative adverbs (ie. here, there, where). Considering the complexity of Deixis study, this study is specifically concerned to the personal deixis of Tukan Besi language.

The Tukang besi language is spoken in the archipelago that bears the same name, the Kepulauan Tukang Besi, east of of the island of Buton in the province of South East Sulawesi, Indonesia. Kepulauan Tukang besi also known as Wakatobi Archipelago. It has four small islands which are have similar language, but different in dialect, they are Wanci or Wangi-wangi island, Kaledupa island, Tomia Island and Binongko island. A linguist, Mark Donohue has done his Research in one island in Tukangbesi archipelago, Kaledupa island, His research about Grammar in Tukang besi language. In his research Donohue did not put deixis in Tukangbesi Language. Whereas, Deixis in Tukangbesi language has unique point of view that really interesting to be researched

\section{Literature Review}

\subsection{Definition of Deixis}

Understanding the definition of deixis, many linguists have presented the definition of deixis variously. Jaszczolt (2002: 191) states that 'deixis' derives from Ancient Greek which means 'to show', 'to point out. Deixis is the phenomenon of encoding contextual information by means of lexical items of grammatical distinctions that provide this information only when paired with this context. In other words, it means lexicalizing or grammaticalizing contextual information, that is making it into obligatory grammatical or lexical distinctions. They give instructions to the addressee that context has to be consulted in order to grasp the meaning of the utterance.

Fromkin in her book "An Introduction to Language (1998: 199) says that in all languages there are many words and expressions whose reference relies entirely on the situational context of the utterance and can only be understood in light of these circumstances. This aspect of pragmatics is called deixis. First and second person pronouns such as; my, mine, you, your, yours, we, ours, and us are always deictic because their reference is entirely dependent on context. You must know who the speaker and listener are in order to interpret them.

Meanwhile, Yule (1996:9) states that deixis is a technical term (from Greek) for one of the most basic things we do with utterances. It means 'pointing' is called a deictic expression. Hurford (1984:63) also states that a deictic word is one which takes some element of its meaning from the situation (i.e. the speaker, the addressee, the time and the 
place) of the utterance in which it is used. Furthermore, Jack Richards, et.al (1985:75) states in their book "Longman Dictionary of Applied Linguistics" that deixis is a term for a word or phrase which directly relates an utterance to a time, place, or person(s).

Since deictic expressions only require meaning when interpreted by the hearer, they belong to the domain of pragmatics. However, since the resolution of their meaning is necessary in order to know the meaning of the proposition and its truth conditions, then at the same time they are in the domain of semantics. In other words, in the case of deictic expressions, the pragmatic processes of reference resolution intrude into the semantics. Generally, deictic expressions are slots, place-holders for referring expressions, which in turn are provided by the context, that is by the situation, previous discourse, pointing and so forth.

In pragmatics and linguistics, deixis is a process whereby words or expressions rely absolutely on context. A word that depends on deictic clues is called a deictic or a deictic word. Pro-forms are generally considered to be deictics, but a finer distinction is often made between personal pro-forms such as I, you, and it (commonly referred to as personal pronouns) and pro-forms that refer to places and times such as now, then, here, there. In most texts, the word deictic implies the latter but not necessarily the former.

It is common for languages to show at least a two-way referential distinction in their deictic system: proximal, i.e. near or closer to the speaker, and distal, i.e. far from the speaker and/or closer to the addressee. English exemplifies this with such pairs as this and that, here and there, etc. in other languages the distinction is three-way: proximal, i.e. near the speaker, medial, i.e. near the addressee, and distal, i.e. far from both.

It is clear that the meaning of utterance in deictic expression can be interpreted through context and we must know who the speaker and listener are being interpreted by certain situation.

\subsection{Personal deixis}

Person deixis encodes the role of participants in the speech event, such as speaker, addressee, other entities. Person deixis is encoded in pronouns: 'l' for the speaker, 'you' for the addressee, 'he', 'she', 'it', 'we', 'they', for others. Pronoun system different from language to language: different information is grammaticalized. Person deixis can be grasped only when we understand the roles of the speaker, source of the utterance, recipient, the target of the utterance, and hearers who are not addressees or targets. Only then can we successfully replace the pronoun and adjectives as in the examples of (a) by those in (b) or (c) in processing the utterance.

(a) Give me your hand.

(b) Give him your hand.

(c) I give him my hand.

\section{Reseach Method}

In this research descriptive qualitative method is used to reveal the types of deixis that used in English and Tukang besi with contrastive analysis to find differences and similarities between deixis in English and Tukang Besi. English data were obtained from library study whether Tukang Besi data were taken from recording (natural conversation) and interview which are take place in Tomia island (at wakatobi Regency). Considering the objective of this research that is to analyze personal deixis of English and Tukangbesi 
Language, therefore in collecting the data of Tukangbesi language, the writer uses notetaking technique and recording. then, the writer will write down each sentence and devide them into some category of deixis.

\section{Discussion}

\subsection{Personal Deixis in English and Tukang Besi}

\section{a. Personal Deictic Systems in English and Tukang Besi:}

According the concept of the pronoun is existent in the two languages. Both the languages regard the pronoun as a subclass of noun that is used as a substitution. The personal concept also is the same in the two languages, i.e. the first person refers to the speaker(s), the second to the addressee(s), and the third to neither speaker(s) nor addressee(s). The subject personal pronoun system of the two languages is greatly different. English is a five person system, while Arabic is an eight-person system. This can be illustrated in the following tables:

Table1. English and Tukang Besi personal deictic systems:

\begin{tabular}{lllll}
\hline & English & & \multicolumn{2}{l}{ Tukang Besi } \\
& Sg & Pl & Sg & Pl \\
\hline 1st person & I & We & Yaku & Kita, kami \\
\hline 2nd person & You & & Ko'o & Komiu \\
\hline 3rd person & He & They & lya & Ammai \\
\hline
\end{tabular}

In English, the personal pronoun system is of one set (separate type), as in Tukang Besi language Moreover, the number of personal pronouns does vary in the two languages. For example, the total number of subject personal pronouns in English is seven: I, He, She, It, You, We, and They; while in Tukang Besi, there are also seven personal pronouns, they are; yaku,kita, kami, ko'o, komiu, iya, ammai. There are no word which has same meaning with "it" in Tukang Besi. Tukang Besi People only use the name of things directly without use an "it"

\section{b. First Person: Semantic and Pragmatic Similarities and Differences:}

In the light of the foregoing survey of the two preceding chapters, the first person in the two languages shows entire similarity in terms of their semantic features. Semantically speaking, the first person singular and plural in both the languages, English and Tukang Besi, show identical meaning. In both the languages, the singular form is used by a single person to refer to himself/herself; while the plural form is used to refer to a group.

For instance, the two languages inflect for singular and plural. Both the languages exhibit no gender distinction in the deictic forms of the first person. The form 'I' in English and the counterpart equivalence yaku in Tukang Besi denote the speaker (either male or female) who refers to himself/herself. The following deictic features can be given for the first person singular form of the two languages. 
Similarly, the first person plural 'we' in English and 'kami' or 'kita' in Tukang Besi denotes a group of people including the speaker who represents them in the speech act. The deictic unit of features is identical in the two languages:

As regards the uses of the first person, the two languages expose similar demonstrations in terms of the use of the 'royal we' and 'authorial / editorial we'. In English and Tukang Besi the plural form is used by a single person as the royal 'we' to establish a social distance and status between the speaker/writer and the audience/ reader. Examples to illustrate this are as follows:

- ikami, te anano Haji Kadiri kene Sitti Hajijah, no tudhu kami to bhawa te samanno Haji Ali (we, the son of Haji Kadir and siti Hajijah, they ask me to give the order of Haji Ali)

- We are not interested in the possibilities of defeat. (Queen Victoria)

For instance, the use of the editorial and authorial 'we' in both the languages show different types as in English, they use "we" to avoid self-focalization and egotisticalness. Illustrative examples are: "In the next chapter we will describe the methodology used"; whether, in Tukang Besi still use "yaku" while speak and give the code for their selves, as follows; "lalo pobisaraa asafalinno, kugumambara akone te carano"

The usage form of 'kami' and 'kita' in Tukang Besi language has different semantic use. word 'kita' as plural first person only use betweeen speaker and speaker to encodes their position as the subject only but word 'kami' is used between speaker and hearer. Illustrative examples are the following;

'kita' : Ta mete umpa nakita ana?

(we will go to where, we are?)

'kami' : a : ye mai i maiso? (who are there)

b : i kami (we are)

\section{c. Second Person: Semantic and Pragmatic Similarities and Differences}

The number of second person pronouns in the Tukang Besi personal system is more than in English. In English, they only use 'you' as second person. But in Tukang Besi they use 'ko'o' which means 'you' in English and 'komiu' which means 'some of you' in English. So, 'ko'o' is for singular dan 'komiu' is for plural.

Pragmatically speaking, the use of the second person in request maximize the politeness intended to express. According to the politeness principle that says "for greater degree of politeness, minimize the speaker's egocentric role in the utterance'. To achieve this goal, the minimization of speaker's focalization will be obtained by shifting away his/her role to the addressee's. Therefore, the use of 'you' in request are regarded more polite and respectful due to the claim that using 'you' in request shift the control and focus from the speaker's center to the addressee's. Therefore, Tukang Besi shows more expressivity of this point for two respects: the first is its lexicalization of the singular second person. Secondly, the plural form of the second person in Tukang Besi is lexicalized and so the effect and the reaction of using plural form for addressing is highly polite and increasingly showing respect. 


\section{Conclusion}

The personal deictic systems of the two languages have been examined and more differences than similarities are displayed. The sole similarity between the two languages is the separate pronouns of the first person, while the second person is highly different. In English, the personal pronoun system is of one set (separate type), as in Tukang Besi language Moreover, the number of personal pronouns does vary in the two languages. For example, the total number of subject personal pronouns in English is seven: I, He, She, It, You, We, and They; while in Tukang Besi, there are also seven personal pronouns, they are; yaku,kita, kami, ko'o, komiu, iya, ammai. There are no word which has same meaning with "it" in Tukang Besi. Tukang Besi People only use the name of things directly without use an "it".

\section{References}

Donohue, Mark (1999) A grammar of Tukang Besi. Berlin ; New York : Mauton de Gruyter.

Fromkin, Victoria and Robert Rodman. 1998. An Introduction to Language. Harcourt Brace College Publishers.

Hurford, James R and Brendan Heasly. (1984). Semantics: a course book. Cambridge University Press.

Jaszczolt, K.M. 2002. Semantics and Pragmatics. Longman.

Levinson, Stephen C. 1983. Pragmatics. Cambridge: Cambridge University Press.

Richard, J; John. P \& Heidi Weber. (1985). Longman Dictionary of Applied Linguistics. Longman.

Yule, G. (1996). PRAGMATICS. Oxford University Press 